Iukhno Nataliia. Development and theoretical substantiation of technology of formation of information and digital competence of medical students vocational colleges. Journal of Education, Health and Sport. 2020;10(9):1038-1049. eISSN 2391-8306. DOI http://dx.doi.org/10.12775/JEHS.2020.10.09.122

https://apcz.umk.pl/czasopisma/index.php/JEHS/article/view/JEHS.2020.10.09.122

https://zenodo.org/record/4421767

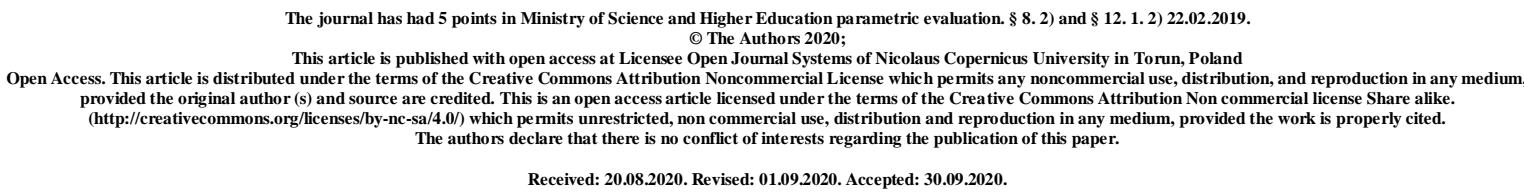

UDC: $377.6: 61$

\title{
DEVELOPMENT AND THEORETICAL SUBSTANTIATION OF TECHNOLOGY OF FORMATION OF INFORMATION AND DIGITAL COMPETENCE OF MEDICAL STUDENTS VOCATIONAL COLLEGES
}

\author{
Nataliia Iukhno \\ H. S. Skovoroda Kharkiv National Pedagogical University, Ukraine \\ yukhno.natalya@i.ua \\ ORCID 0000-0002-6412-3101
}

\begin{abstract}
The article is devoted to the problem of formation of information and digital competence of students of medical vocational colleges. The scientific analysis of the content of the concepts "information and digital competence" is carried out. The components of information and digital competence of students of medical vocational colleges are determined. Criteria (motivational, cognitive-informational, procedural, reflective-effective), indicators (motives, needs, interests that motivate the formation of information and digital competence of students of medical vocational colleges; positive attitude of students to the formation of information and digital competence; desire to use ICT training in the process of occupational practice, understanding the role of information and prospects for the use of ICT in medicine, knowledge of basic concepts related to ICT training, information and digital tools in educational and professional activities, a set of skills needed by a medical vocational college student to search, transmission and storage of information, the ability to adequately assess their own activities using ICT training in medicine, control, self-control, evaluation and self-
\end{abstract}


evaluation of the process and results of activities for further reassessment) and the level of readiness of information and digital competence of students of medical vocational colleges (high, medium, low). The technology of formation of information-digital competence of students of medical vocational colleges, which includes motivational-target, cognitiveactivity, reflection-corrective stages, is scientifically substantiated and developed. The effectiveness of the technology is ensured by the following didactic conditions: actualization of motivational and value training of medical vocational college students; organization of interaction of students and teachers of medical vocational colleges on the Internet through the creation of information and digital learning environment based on individual student support; creation of individual educational routes of students during training and occupational practices.

Keywords: information and digital competence; student; medical vocational college; educational process; technology; formation; components; criteria.

\section{Introduction}

Currently, the vocational education system around the world is taking steps to organize education in a pandemic (COVID-19). Teachers and students had to face unexpected difficulties due to the introduction of self-isolation. If the higher education system has so far functioned quite effectively online, the vocational education system has not been ready for self-isolation. The current state of development of information and digital technologies gives grounds to claim that humanity living in the era of "digital society" is changing its attitude to the real world and the digital environment [5]. This trend is caused by the constant increase in information, because every year, thanks to technological progress, society receives new means of obtaining data and communication between people [5]. Thus, the future specialist, who does not want to remain on the periphery of modern society, must clearly understand that without the skills to work with digital communications, mobile devices and the web environment will not be able to fully realize their potential in today's reality.

The transformation of our society is changing the perception of quality modern education. In our opinion, given the gradual digitization of education in the world, one of the current problems that exists in the domestic vocational higher education system is the insufficient material and technical base of domestic educational institutions, which somewhat slows down the consistent introduction of information and digital technologies in the educational process. It should also be noted that this process is slowed down by insufficient preparation of teachers and students of medical vocational colleges to work in the format of 
blended-digital learning, in particular: low technical competence of participants in the educational process, which is associated with problems in mastering new technologies and low readiness to use them in education [3].

The rapid pace of informatization and globalization of modern society affects the professional activities of specialists in all fields of science. For example, domestic scientist V. Bykov emphasizes that "the degree of introduction of digital technologies in education largely reflects the depth and scale of informatization of society, and this process itself is comprehensive in relation to the education system. That is why the introduction of digital technologies in the educational process contributes to most of the tasks facing the domestic education system" [9]. Therefore, there is an urgent need to form students of knowledge, skills and abilities to work in the information-digital educational environment. But it's impossible without the formation of information and digital competence of students, in particular students of medical vocational colleges.

\section{Analysis of scientific research}

The theoretical analysis of scientific research and publications gave grounds to claim that the problems of formation of information and digital competence of future specialists in higher education institutions were studied by many domestic and foreign scientists (V. Bykov and M. Leshchenko [2], O. Zhernovnikova [12], A. Ferrari [3], L. Ilomäki, A. Kantosalo, M. Lakkala [4], R. Vuorikari, Y. Punie [8], G. Merchant [6], C. Scott [7] and others). However, the issue of formation of information and digital competence of students of medical vocational colleges is insufficiently covered in the scientific literature.

The purpose of the article - theoretically substantiate and develop the technology of formation of information and digital competence of students of medical vocational colleges.

\section{Presenting main material}

The introduction of innovative technologies for working with future professionals in the modern system of training does not lose its relevance primarily because employers do not reduce, but, on the contrary, increase the requirements for graduates of medical vocational colleges. Based on this, it can be stated that now a student of medical vocational college requires not only educational documents, but also their practical confirmation in the form of formed relevant competencies, which contain practical skills, abilities and readiness to implement them. Traditional education mostly contributes to the formation of theoretical knowledge of students, and the introduction of innovative forms, methods and tools in the educational process aims to form key and basic competencies. 
The analysis of scientific publications [15], [16], [5] determined that in modern science there is no unanimous point of view on the definition of "competence", so, in our opinion, the most successful definition will be given in the state legal act, in particular in the Ministerial guidelines for the development of higher education standards, where competence is interpreted as "a dynamic combination of knowledge, skills, thinking, attitudes, values, other personal qualities that determine a person's ability to successfully socialize, pursue professional and / or further educational activities" [14].

Studies of the scientific literature [16], [5], [1] have shown that information-digital competence, like other key competencies, does not have a single definition. O. Zhernovnikova characterizes it as universal methods of transmission, receipt, search, processing, provision, generalization, systematization, transformation of information into knowledge [13, p. 223].

S. Scott understands information and digital competence as the ability to use digital media and information and communication technologies with a clear understanding and critical approach to the effective use of communication in various life situations [7].

One of the effective means of forming information and digital competence of students of medical vocational colleges is the use of mobile-digital applications as one of the main means of communication and reproduction of digital content for most students. Confirmation of the above is a study by a group of scientists led by Professor O. Romanovsky on the formation of digital competence of future professionals [16].

It should be noted that most students of medical vocational colleges have a positive attitude to the use of multimedia materials during the educational process and often develop relevant materials in the context of the formation of information and digital competence. Modern digital devices can easily combine all types of information: animation, video, graphics and text, which greatly facilitates the creation of high quality and unique multimedia content.

The above provides grounds to assert that the result of the formation of information and digital competence of students of medical vocational colleges is the formed competence for this type of activity. In the structure of the formed information and digital competence of students of medical vocational colleges the interconnected components are singled out motivational-axiological, cognitive, operational-activity and personal-reflective, in determining the content of which the educational-qualification characteristics of the medical vocational graduate were taken into account and also features of professional activity in the specified aspect. 
The motivational-axiological component of information-digital competence reflects the presence of: sustained interest; a stable system of motives, the needs of future professionals and their installation on the formation of information and digital competence. The cognitive component of information and digital competence in students of medical vocational college contains a set of knowledge in computer science and disciplines of the professional-practical cycle. The operational-activity component of information and digital competence is implemented through a set of skills (gnostic, projective, constructive, organizational, communicative, intellectual, evaluative-reflective, research, professional), which contribute to formation of students of medical vocational colleges the ability to use information and digital technologies in future professional activities. The personal-reflective component of the information-digital competence of medical vocational college students to professional activity is revealed through the development and formation of the future specialist as a person, the ability to professional reflection.

The analysis of literature sources allows to state that most often didactic and pedagogical conditions are used for strengthening in the course of introduction in educational process of the developed technologies. In the aspect of our research the following pedagogical conditions are defined: actualization of motivational and value preparation of students of medical vocational colleges; organization of interaction of students and teachers of medical vocational colleges on the Internet through the creation of information and digital learning environment based on individual student support; creation of individual educational routes of students during training and occupational practices.

Thus, the first didactic condition is the actualization of the motivational and value component of the training of medical vocational college students. It should be noted that one of the main areas of higher education today is the professional orientation of the future specialist, which reflects the system of educational and professional motivation, interest in future professional activities, professionally significant qualities, values. Theoretical and practical value of knowledge and skills, their significance for personal development, value for future professional activity, the need to master the methods of cognitive activity are the main motives of cognitive activity $[10 ; 11 ; 17]$.

The cognitive activity of the future specialist is the basis of the motivational and value sphere of personality. The need, which turns into a motive, contributes to the formation of different levels of motivation for professional development of the individual, and one of the most important elements of the motivational system is interest. 
Thus, professional interest is formed on the basis of cognitive awareness, lack of knowledge and motivates students to search, analyze new professionally relevant information, i.e. cognitive interest arises as a conscious need to form information and digital competence of medical vocational college students.

The second pedagogical condition is the organization of interaction between students and teachers of medical vocational colleges on the Internet through the creation of information and digital learning environment based on individual student support.

The study of the etymology of the essence of the concept of "support" gave grounds to consider it as joint actions (system, process, type of activity) of people in relation to each other in their social environment.

At the level of general understanding, human support is a social interaction with others, the functions of the influence of which is the development of this person in life, in various personal and social situations. Such support can be of different nature. This definition is confirmed by the fact that in practical activities and scientific literature there are such concepts as "medical support", "psychological support", "scientific support" and so on.

One of these types of support is pedagogical support, which, firstly, contains features of social interaction, and secondly, has its own specifics. This specificity lies in the pedagogical nature of support, the purpose of which is the purposeful development of the individual, which is accompanied and carried out by special pedagogical systems (education, upbringing, training, preparation) in their institutional (structural) design.

Let's highlight the main provisions of the concept of student support: the complexity of the approach to solving problems facing students (individual routes, the interaction of student and teacher on the Internet); the need to accompany rather than guide the student's development, consolidating his ability to make decisions independently; improving information support by solving the problem.

In the course of the research it was established that the process of individual support involves an active position of the student to obtain the necessary amount of knowledge, skills, and ways to gain experience of independent cognitive activity.

The next pedagogical condition is the creation of individual educational routes for students during training and occupational practices.

Vocational training, built using individual educational routes, firstly, allows to implement a personal approach in the education of students, which takes into account their intellectual abilities, and secondly, determines the personal trajectory of educational development in the process of training and occupational practices. In this case, the personal 
educational process is implemented as an individual educational route using the functional possibilities of pedagogical support.

The structure of the individual route contains components: target (setting goals for education, based on state standards, motives and needs of medical vocational college students); content (structure and selection of content, systematization and grouping, establishing interdisciplinary links); diagnostic (determination of the diagnostic system of such support); organizational and pedagogical (conditions and ways to achieve the goal).

Thus, when constructing the educational route of medical college students in the process of training and occupational practices should use the following algorithm: diagnosis of the level of development and severity of personal qualities of medical students. At this stage, the main needs and motives of students, the readiness of medical college students for digital learning, the initial level of knowledge and skills of students; each student builds his individual educational image of the topic, determines individual goals; formulates the attitude to the specified problems; predicts its success, etc.; demonstration of personal results and achievements during training and occupational practices. At this stage, each student or group of students provides their learning outcomes, a collective discussion is held. Work is organized to identify shortcomings, problems faced by students.

The result of comprehension and generalization of theoretical achievements of scientists on the researched problem and own practical experience became development of technology of formation of information and digital competence of students of medical professional colleges which conceptual basis consists of scientific approaches (system, personality-oriented, information and activity) and the basic principles of organization of the learning process (scientific, systematic and consistent, accessibility, connection of learning with life, clarity, strength of knowledge, continuity, individual approach, humanization, differentiation, interdisciplinary integration, creativity, etc.).

The developed technology of formation of information and digital competence of students of medical vocational colleges includes the following stages:

- motivational-target, which ensures the formation of students of medical vocational colleges of the relevant motives, needs, interests, values; students learn to identify professional problems, analyze problem situations, identify contradictions, determine the purpose and main possibilities of digital learning in the process of professional training (at this stage the first didactic condition is realized - actualization of motivational and value training of medical college students); 
- cognitive-activity, which includes theoretical, practical and scientific-methodical training of students, which is realized through the appropriate choice of forms, methods and means of vocational training; students develop skills and abilities of analysis, comparison, analogy, synthesis of information; they master the skills and abilities of presentation and defense of the project, analysis of achieving the goal and solving problems, participation of each student in the project for the implementation of information and digital technologies in future professional activities (at this stage the second didactic condition is implemented organization of interaction of students and teachers of medical vocational colleges on the Internet through the creation of information and digital learning environment based on the individual student support);

- reflective-corrective, which corrects the content, forms and methods of appropriate training of medical vocational college students for the formation of information and digital competence based on teacher assessment and self-assessment of students of the effectiveness of the introduced technology (at this stage the third didactic condition is implemented creating individual educational routes during training and occupational practices).

All three stages ensure the formation of information and digital competence of students of medical vocational colleges.

The expediency of introducing theoretically substantiated and developed technology of formation of information and digital competence of students of medical vocational colleges into the educational process of medical vocational colleges is confirmed by the obtained results of the pilot study. It should be noted that the pilot study was conducted using a set of measurement procedures in accordance with the developed criteria for the formation of information and digital competence of students of medical vocational colleges. Thus, the level of formation of information and digital competence of students of medical vocational colleges is tracked (table 1).

The motivational criterion for the formation of information and digital competence of students of medical vocational colleges was tested by conducting interviews and questionnaires, as well as the introduction of the method "Diagnosis of values and motives of students".

Thus, in the process of research we found that the indicators of the motivational criterion (motives, needs, interests that motivate the formation of information and digital competence of students of medical vocational colleges; positive attitude of students to the formation of information and digital competence; desire to apply ICT learning in the process 
of occupational practice) have a low level of formation, and a high level of evaluation by motivational criteria is completely absent.

Cognitive-informational criterion of formation of information-digital competence of students of medical vocational colleges was checked by testing and introduction of the method "Diagnosis of knowledge, skills, abilities of students", based on which the level of knowledge and skills to work in information-digital environment was tested.

As a result, we obtained mostly low and medium levels in such indicators as: understanding the role of information and prospects for the use of ICT in medicine; knowledge of basic concepts related to ICT learning, information and digital tools in educational and professional activities. Only $2.6 \%$ of respondents recorded a high level.

The processual criterion was tested by introducing the method "Diagnosis of the level of technological readiness of students", which tested the skills and abilities, as well as understanding of the possibilities of information and digital technologies in professional activities. Training was a prerequisite at this stage.

Thus, the indicators by which the processual criterion was evaluated (the set of skills needed by a medical vocational college student to search, transmit and store information) reach $10 \%$ of respondents, which is much higher than other criteria.

Table 1

The results of a pilot study on the formation of information and digital competence of students of medical vocational colleges

\begin{tabular}{|c|c|c|c|}
\hline \multirow{2}{*}{ Criteria } & \multirow{2}{*}{$\begin{array}{l}\frac{n}{0} \\
\frac{0}{3}\end{array}$} & \multicolumn{2}{|c|}{ Respondents (416 people) } \\
\hline & & $\%$ & Absolute data \\
\hline \multirow[t]{3}{*}{ Motivational } & $\mathrm{H}$ & - & - \\
\hline & $\mathrm{M}$ & 36,2 & 76 \\
\hline & $\mathrm{L}$ & 63,8 & 132 \\
\hline \multirow[t]{3}{*}{ Cognitive-informational } & $\mathrm{H}$ & 2,6 & 6 \\
\hline & $\mathrm{M}$ & 32,9 & 68 \\
\hline & $\mathrm{L}$ & 64,5 & 134 \\
\hline \multirow[t]{3}{*}{ Processual } & $\mathrm{H}$ & 10,5 & 22 \\
\hline & $\mathrm{M}$ & 43,4 & 90 \\
\hline & $\mathrm{L}$ & 46,1 & 96 \\
\hline \multirow[t]{3}{*}{ Reflective-effective } & $\mathrm{H}$ & - & - \\
\hline & $\mathrm{M}$ & 33,6 & 70 \\
\hline & $\mathrm{L}$ & 66,4 & 138 \\
\hline
\end{tabular}

Note: H - high, M - medium, L - low level of formation of information and digital competence of students of medical vocational colleges 
Reflective-effective criterion of formation of information-digital competence of students of medical vocational colleges was tested by introducing the method "Diagnosis of the level of personality reflexivity", which tested the ability to use acquired knowledge and skills in information-digital environment, to carry out reflective analysis and skills correction. As for the indicators by which the reflection- effective criterion was evaluated (ability to adequately evaluate one's own activity using ICT training in medicine; control, self-control, evaluation and self-evaluation of the process and results of activities for further re-evaluation) are mostly low level, so at the medium level only $33.6 \%$ of respondents.

\section{Conclusions}

Thus, the informatization of society makes clear requirements for the training of a competent specialist in the field of medicine. Education can not stay away from this fundamental process, so one of the main goals of modern higher education in Ukraine is to train professionals with high digital literacy and digital culture, and this is impossible without the formation of information and digital competence of medical students. The application of a set of diagnostic methods in the process of conducting a pilot study allowed us to conclude that the dominance of medium and low levels of information and digital competence of students of medical vocational colleges. The results of the pilot study stated low motivation of students to master information and digital technologies in the educational process $(63.8 \%)$ and low level of general theoretical knowledge and technological skills (46.1\%).

Therefore, the technology of formation of information and digital competence of students of medical vocational colleges is theoretically substantiated and developed. We hope that the introduction of this technology: will promote creative self-realization of students in the information and digital space; increase their motivation for digital learning; will develop students' intellectual abilities; will allow to involve the majority of students in active cognitive activity in the course of training; will promote the formation of the necessary skills of search and research activities in the digital environment; will improve group cooperation of students and develop communication skills; increase digital literacy.

\section{References:}

1. Ala-Mutka K., Punie Y., Redecker C. Digital competence for Lifelong Learning. Luxemburg: Office for Official Publications of the European Communities, 2008. URL: file:///C:/Users/oazhe/Downloads/JRC48708.

TNDigitalCompetencepolicybrief2008.pdf 
2. Bykov V. Yu., Leshchenko M. P. Digital humanistic pedagogy: relevant problems of scientific research in the field of using ICT in education. Information Technologies and Learning Tools, Vol. 53, №3. pp. 1-17, 2016.

3. Ferrari A. Digital Competence in Practice: An Analysis of Frameworks». European Commission Joint Research Center. Institute of Prospective Technologies Studies.: European Union, 2012, 92 p.

4. Ilomäki L., Kantosalo A., Lakkala M. What is digital competence? In Linked portal. Brussels: European Schoolnet, 2011. URL: http://linked.eun.org/web/guest/in-depth3. Accessed on: Feb. 12, 2019.

5. Ilomäki L., Paavola S., Lakkala M., Kantosalo A. Digital competence - an emergent boundary concept for policy and educational research». Education and Information Technologies, Vol. 21, P, 655-679, 2016.

6. Merchant G. Writing the future in the digital age. Literacy, Vol. 41, P. 118128, 2007.

7. Scott C. The futures of learning 3: What kind of pedagogies for the 21st century? 2015. URL: http://unesdoc.unesco.org/images/0024/002431/ 243126e.pdf.

8. Vuorikari R., Punie Y., Carretero Gomez S., Van den Brande G. DigComp 2.0: The Digital Competence Framework for Citizens. Update Phase 1: The Conceptual Reference Model». Luxembourg Publication Office of the European Union. 2016. URL: https://ec.europa.eu/jrc/en/digcomp/digital-competence-framework.

9. Bykov V. Yu. Suchasni zavdannya informatyzatsiyi osvity. Informatsiyni tekhnolohiyi i zasoby navchannya. №1(15). 2010. URL: Dostupno: http://journal.iitta.gov.ua/ index.php/ itlt/article/view/25/13. [in Ukrainian]

10. Volosovets' O. P. Pytannya yakosti osvity u konteksti vprovadzhennya zasad Bolons'koyi deklaratsiyi u vyshchiy medychniy shkoli. Medychna osvita. K., 2005. №2. S. 12-16. [in Ukrainian]

11. Zhernovnykova O. A. Dydaktychni umovy stymulyuvannya samostiynoyi navchal'noyi diyal'nosti studentiv medychnykh koledzhiv: dys. ... kand. ped. nauk: 13.00.09. Kh., 2009. 219 s. [in Ukrainian]

12. Zhernovnykova O., Yefymova T. Tekhnolohiya formuvannya informatsiynotsyfrovoyi kompetentnosti maybutnikh uchyteliv matematyky: teoretychnyy aspekt. Naukovodoslidna robota studentiv yak chynnyk udoskonalennya profesiynoyi pidhotovky maybutn'oho vchytelya, Vyp.17, c.118-132, 2018. [in Ukrainian] 
13. Zhernovnykova O. A. Psykholohichnyy aspekt realizatsiyi dystantsiynykh osvitnikh tekhnolohiy u navchal'nyy protses maybutnikh uchyteliv matematyky. Naukovi zapysky Berdyans'koho derzhavnoho pedahohichnoho universytetu. Pedahohichni nauky, Vyp. 2, S. 219-225, 2017. [in Ukrainian]

14. Metodychni rekomendatsiyi shchodo rozroblennya standartiv vyshchoyi osvity, 2017. [in Ukrainian] URL: https://mon.gov.ua/storage/app/media/vishchaosvita/rekomendatsii1648.pdf.

15. Nalyvayko O. O. Formuvannya informatsiyno-tsyfrovoyi kompetentnosti yak rezul'tatu profesiynoyi pidhotovky studentiv klasychnykh universytetiv». Pedahohichnyy al'manakh, Vyp. 40, 2018, s. 129-134. [in Ukrainian]

16. Romanovs'kyy O. H., Hryn'ova V. M., Zhernovnykova O. A., Shtefan L. A., Fazan V. V. Formuvannya tsyfrovoyi kompetentnosti maybutnikh uchyteliv matematyky: konstatuval'nyy etap». Information Technologies and Learning Tools, vol. 65, №3. pp. 27-39, 2018. URL: http://journal.iitta.gov.ua/index.php/itlt/article/view/1511 [in Ukrainian]

17. Sharlovych Z. P. Formuvannya profesiyno-pedahohichnoyi kompetentnosti medychnykh sester simeynoyi medytsyny v protsesi fakhovoyi pidhotovky: dys. ... kand. ped. nauk: 13.00.04. Zhytomyr, 2015. 255 s. [in Ukrainian] 